\title{
Glaciecola punicea gen. nov., sp. nov. and Glaciecola pallidula gen. nov., sp. nov.: psychrophilic bacteria from Antarctic sea-ice habitats
}

\author{
John P. Bowman, ${ }^{1,2}$ Sharee A. McCammon, ${ }^{2}$ Janelle L. Brown ${ }^{2}$ \\ and Tom A. McMeekin ${ }^{1,2}$ \\ Author for correspondence: John P. Bowman. Tel: +61 3 62262776. Fax: +61362262642 \\ e-mail: john.bowman (a) utas.edu.au
}

Antarctic $\mathrm{CRC}^{1}$ and Department of Agricultural Science?2, University of Tasmania, GPO Box 252-80, Hobart, Tasmania 7001, Australia

\begin{abstract}
A group of pigmented, psychrophilic, strictly aerobic chemoheterotrophs isolated from sea-ice cores collected from coastal areas of eastern Antarctica was found to represent a novel 16S rRNA lineage within the gamma subclass of the Proteobacteria, adjacent to the genus Alteromonas. The isolates are motile, Gram-negative, rod-shaped cells, which are psychrophilic and slightly halophilic, and possess an absolute requirement for seawater. Differences in phenotypic characteristics and DNA-DNA hybridization indicated the isolates formed two distinct taxa which have DNA G+C contents of $44-46 \mathrm{~mol} \%$ and $40 \mathrm{~mol} \%$, respectively. Whole-cell fatty acid profiles of the isolates were however very similar and included 16:1 $\omega 7 c, 18: 1 \omega 7 c, 16: 0$ and $17: 1 \omega 8 c$ as the major fatty acid components. Overall, sufficient differences exist to distinguish the sea-ice strains from currently recognized bacterial genera. It is proposed the sea-ice strains represent a new genus, Glaciecola, which contains two species, Glaciecola punicea gen. nov., sp. nov. (ACAM 611') and Glaciecola pallidula gen. nov., sp. nov. (ACAM 615').
\end{abstract}

Keywords: Antarctica, sea ice, psychrophilic bacteria, Glaciecola gen. nov., Alteromonas

\section{INTRODUCTION}

Sea-ice microbial communities have a major influence on various trophic levels of the polar oceanic food webs (Palmisano \& Garrison, 1993) and occur as surface laver populations, within ice floes, and concentrated near the sea ice/seawater interface. Sea ice represents a permanently cold but temporally and spatially highly variable habitat, rarely lasting longer than a few seasons, with internal temperatures typically ranging from -1 to $-15^{\circ} \mathrm{C}$. The salinity of internal sea-ice brine inclusions correlates to the local in situ ice temperature and ranges from $<10 \%$ to $>150 \%$ (Eicken \& Lange, 1989). The ecological structure and biological rates in sea ice are essentially driven by the prevailing temperature and salinity (Nichols et al., 1995). Nevertheless, sea ice is a biologically dynamic habitat and is in general more productive than the underlying pelagic zone (Dieckmann et al., 1992). Bacterial populations are tightly coupled to primary productivity levels in sea-ice microbial communities (Grossi et al., 1984) and have been observed heavily colonizing the surfaces of several ice diatom species, particularly those in the process of senescence. Phenotypic and 16S rRNA phylogenetic-based surveys of sea-ice bacteria (Bowman et al., 1997a, b; Delille, 1996; Gosink \& Staley, 1995; Irgens et al., 1989) indicate sea ice has a diverse bacterial population dominated by psychrophilic bacteria which appear to be absent from the underlying pelagic zone. In this study, two groups of psychrophilic sea-ice isolates, one pigmented and another coloured pale pink, forming a novel $16 \mathrm{~S}$ rRNA lineage adjacent to the genus Alteromonas (Proteobacteria, gamma subclass) were investigated. On the basis of polyphasic taxonomic characterization, the two groups of strains represent two distinct species in a novel genus, Glaciecola gen. nov.

\section{METHODS}

Isolation and cultivation. The isolation and initial phenotypic analysis of strains investigated in this study has been previously described (Bowman et al., 1997a). In summary, 
sea-ice cores were melted in an equal volume of seawater at $2-4{ }^{\circ} \mathrm{C}$ to avoid hypotonic shock of halophilic bacteria, diluted to an approximately $1: 10$ ratio in marine 2216 liquid media at $2{ }^{\circ} \mathrm{C}$ and incubated for $1-2 \mathrm{~d}$ before being serially diluted onto marine 2216 agar. Plates were then incubated at $2-4{ }^{\circ} \mathrm{C}$ for up to 2 months before colonies were subcultured for purification. Colonies were then restreaked on fresh plates for purification of individual strains. The sea-ice isolates were routinely cultivated on marine 2216 agar at $5-10{ }^{\circ} \mathrm{C}$.

Phenotypic characterization. Gram-stain, oxidase and catalase tests were performed as described by Smibert \& Krieg (1994). Motility was tested by microscopically examining cell wet mounts. Growth at different temperatures was tested in marine 2216 liquid media in $10 \mathrm{ml}$ screw-cap tubes and incubated in a series of controlled temperature waterbaths set at different temperatures. Seawater requirement and tolerance of various $\mathrm{NaCl}$ concentrations $(0-12 \%$ $\mathrm{NaCl}$ ) was tested in $\mathrm{R} 2 \mathrm{~A}$ agar (Oxoid). Hydrolysis of Tween 80, starch, egg-yolk, aesculin and casein was tested as described by Smibert \& Krieg (1994) using marine 2216 agar as the basal medium. DNA hydrolysis was tested using DNase test agar (Oxoid) supplemented with artificial seawater. Chitin and alginate hydrolysis was tested on media prepared with artificial seawater (West \& Colwell, 1984). Additional biochemical tests were performed using the API $20 \mathrm{E}$ and API 32 ID test kits (bioMérieux) which were prepared according to the manufacturer's specifications except that bacterial strains were suspended in chilled artificial sea water. The oxidation/fermentation $(\mathrm{O} / \mathrm{F})$ medium of Leifson (1963) was used for testing acid production from carbohydrates. Dissimilatory iron reduction was tested in a medium adapted from Widdel \& Bak (1992) and prepared using the Hungate technique (Hungate, 1968). The medium prepared with artificial seawater contained $10 \mathrm{mM}$ amorphic ferric oxide/neutralized ferric chloride or $10 \mathrm{mM}$ soluble ferric oxide/ferric pyrophosphate (Lovely \& Phillips, 1986) as the electron acceptors and $10 \mathrm{mM}$ sodium lactate as the electron donor and carbon source. Uninoculated controls lacking the iron electron donor were also prepared. Iron reduction was confirmed by the appearance of black precipitate (magnetite) and by use of the Merckoquant Iron Test (Merck). Anaerobic growth with $10 \mathrm{mM}$ trimethylamine $N$-oxide (TMAO) was tested in mineral salts medium containing (per litre artificial sea water): $2 \mathrm{~g}$ ammonium chloride, $2 \mathrm{mM}$ potassium phosphate buffer $\mathrm{pH} 7 \cdot 0,2 \mathrm{ml} \mathrm{SL}-10$ trace element solution (Overmann \& Pfennig, 1989), $1 \mathrm{~g}$ yeast extract and $10 \mathrm{ml}$ vitamin solution no. 6 (Staley et al., 1992). The medium $\mathrm{pH}$ was adjusted to 7.0 using $1 \mathrm{M} \mathrm{KOH}$ and was solidified with $1.3 \%$ $(\mathrm{w} / \mathrm{v})$ purified agar (Oxoid). Sodium acetate $(20 \mathrm{mM})$ was used as the electron donor and carbon source. Plates were incubated in an anaerobic jar using Anaerogen gaspaks (Oxoid). Growth on the plates was compared with control plates lacking TMAO. Carbon and energy substrate screening utilized $0.1 \%(\mathrm{w} / \mathrm{v})$ concentrations of test compounds, except carbohydrates, which were tested at a concentration of $0.2 \%(\mathrm{w} / \mathrm{v})$. The basal medium used was the same as that utilized for the TMAO reduction test shown above. Media lacking a carbon source were prepared as negative controls to take account of background growth.

Numerical taxonomy. Phenotypic data were recorded in a compressed binomial format and analysed using computer software. A matrix of Jaccard similarity values was calculated by using the software package TAXON version 1 (Ross \& Shields, 1993). Cluster analysis used unweighted pair-group averaging, which was calculated using the NEIGHBOR program from the PHYLIP version $3.57 \mathrm{c}$ software package (Felsenstein, 1993).

Genotypic analysis. Genomic DNA was extracted and purified from cells grown on marine 2216 agar for 3-7 d at $10^{\circ} \mathrm{C}$ (Marmur \& Doty, 1962). The DNA G $+\mathrm{C}$ content was then determined from thermal denaturation $\left(T_{\mathrm{m}}\right)$ profiles (Sly et al., 1986).

The spectrophotometric renaturation rate kinetic procedure as adapted by Huss et al. (1983) was used to determine DNA-DNA reassociation values between genomic DNA of different strains. Genomic DNA was sheared to a mean size of $1 \mathrm{~kb}$ using sonication, dialysed overnight at $4{ }^{\circ} \mathrm{C}$ in $2 \times$ SSC buffer ( $0.3 \mathrm{M} \mathrm{NaCl}, 0.03 \mathrm{M}$ sodium citrate, $\mathrm{pH} 7.0)$ and adjusted in concentration to approximately $75 \mu \mathrm{g} \mathrm{ml} \mathrm{m}^{-1}$. Following denaturation of the DNA samples, hybridization was performed at the optimal temperature for renaturation $\left(T_{\text {OR }}\right)$ which was $25^{\circ} \mathrm{C}$ below the DNA melting temperature and was calculated from the following equation: $T_{\text {or }}{ }^{\circ} \mathrm{C}=$ $48.5+(0.41 \times \mathrm{mol} \% \mathrm{G}+\mathrm{C})$. The decline in absorbance of DNA mixtures and control DNA samples over a $40 \mathrm{~min}$ interval was used to calculate DNA hybridization values from the following equation (Huss et al., 1983):

$\%$ DNA hybridization $=$

$[4 \mathrm{AB}-\mathrm{A}-\mathrm{B} / 2 \sqrt{\mathrm{A}} \times \mathrm{B})] \times 100 \%$

$A$ and $B$ each represent the change in absorbance for two different DNA samples being compared and $\mathrm{AB}$ represents the change in absorbance for equimolar mixtures of $\mathrm{A}$ and $\mathrm{B}$. DNA hybridization values equal to or below $25 \%$ are considered to represent background hybridization and are thus not considered significant (Huss et al., 1983).

Fatty acid analysis. Representative strains and Alteromonas macleodii subsp. macleodii NCIMB $1963^{\mathrm{T}}$ were grown in marine 2216 broth at $15^{\circ} \mathrm{C}$ for $1-4 \mathrm{~d}$, harvested into a small amount of artificial seawater and then lyophilized using a vacuum freeze-drier (Dynavac). Whole-cell fatty acid profiles were quantitatively determined using GC and GCMS procedures (Nichols \& Russell, 1996). The geometry and position of double bonds in monounsaturated fatty acids was confirmed using dimethyldisulfide derivatization and analysis using GC-MS. The double bond positions are numbered from the methyl $(\omega)$ end of the fatty acid.

Phylogenetic analysis. The 16S rRNA gene sequences for representatives of the sea isolates (ACAM 610, ACAM 611 ${ }^{\mathrm{T}}$, ACAM 613 and ACAM 615 ) were obtained in an earlier study of sea-ice bacteria (Bowman et al., 1997b) and have been deposited under GenBank accession nos U85851U85854. These sequences were compared to the compilation of $16 \mathrm{~S}$ rRNA genes available in the GenBank nucleotide library using BLAST searching (Altschul et al., 1990) through the US National Institutes of Health internet site and then aligned with related sequences of the gamma subclass (Proteobacteria). Subsequent phylogenetic analyses of the sequence data sets utilized PHYLIP version $3.57 \mathrm{c}$ (Felsenstein, 1993). DNADIST was used to determine sequence similarities using the maximum-likelihood algorithm option. Phylogenetic trees were constructed with the Fitch-Margoliash method by using the program FITCH. Bootstrap analysis using 1000 replicates utilized the programs SEQBOOT and CONSENSE. For construction of the phylogenetic tree, the sequence of Psychrobacter immobilis was used as the outgroup. Sequences used for comparison included (GenBank accession no. in parentheses): Alteromonas macleodii subsp. macleodii IAM $12920^{\mathrm{T}}$ (X82145), Alteromonas macleodii 
subsp. fijiensis CNCM I-1627 ${ }^{\mathrm{T}}$ (X85174), 'Alteromonas infernus" (NCM I-1628 ${ }^{\mathrm{T}}$ (X85175), 'Arhodomonas oleiferhydrans 'ATCC 49307' (M26631), Chromohalobacter marismortıi ATCC $17056^{\mathrm{T}}$ (X87210), barotolerant strain CNPT3 (L 91588), Colwellia psychrerythraea ATCC 27634 (AF001375), Ferrimonas balearica DSM 9799 ${ }^{\mathrm{T}}$ (X93021), Halomonas elongata ATCC $33173^{\mathrm{T}}$ (M93355), Marinobacter hydrocarbonoclasticus ATCC 49840 ${ }^{\mathrm{T}}$ (X67022) Marinobacterium georgiense ATCC $700074^{\mathrm{T}}$ (U58339), Marinomonas vaga ATCC 271197 (X67025), Microbulbifer hydrolyticus ATCC $700072^{\mathrm{T}}$ (U58338), Oceanospirillum linum ATCC 11336 ${ }^{\mathrm{T}}$ (M22365), Pseudoalteromonas haloplanktis ATCC $14.393^{\mathrm{T}}$ (X67024), Psychrobacter immobilis ATCC $43116^{\mathrm{T}}$ (L39399), Shewanella putrefaciens ATCC 8071 (X82133), Vibrio cholerae ATCC $14035^{\mathrm{T}}$ (X74695), and [Vibrio] marinus NCIMB $1144^{\mathrm{T}}$ (X82142).

\section{RESULTS}

\section{Numerical taxonomic analysis}

Polyphasic taxonomic data from this and earlier studies was used to assess the phenotypic diversity and systematics of a group of pink-red- and pale-pinkpigmented, seawater-requiring psychrophilic bacterial strains isolated from sea ice (Table 1). The group was identified as a novel and coherent phylogenetic group in the gamma subclass of the Proteobacteria (Bowman et al., 1997b). Numerical taxonomic analysis calcu- lated on the basis of simple matching coefficients indicated the strains formed a single group sharing a similarity of approximately $80 \%$. In this study, Jaccard similarity coefficients $\left(S_{J}\right)$ were used to better discriminate between strains and thus provide a clearer picture of phenotypic variations amongst the novel strains. Applying this procedure, two distinct phenetic

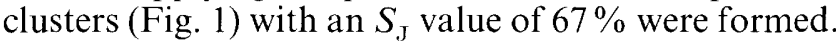
The first cluster included 15 strains all possessing a bright red-pink pigmentation. The remaining strains possessed a pale pink pigmentation and form a second cluster. By comparison the $A$. macleodii reference strain possessed $S_{\mathrm{J}}$ values of only $45 \%$ to the sea-ice strains (Fig. 1). In this study, it is demonstrated that each of these clusters constitutes a species in a novel genus, with the first cluster designated Glaciecola punicea and the second cluster called Glaciecola pallidula.

\section{Cellular and colony morphology}

G. punicea strains possessed colonies which were pigmented pink-red, circular and convex in shape, with lobate edges, a butyrous consistency and 3-5 mm in diameter after $14 \mathrm{~d}$ incubation. The colonies of $G$. pallidula were pale pink, circular and convex in shape, entire-edged with a butyrous-mucoid consistency and

Table 1. Antarctic sea-ice isolates investigated in this study

\begin{tabular}{|c|c|}
\hline Strains* & Antarctic sea-ice sampling sites \\
\hline \multicolumn{2}{|l|}{ G. punicea gen. nov., sp. nov. } \\
\hline $\operatorname{IC036}(=$ ACAM 612) & Shirokaya Bay, Long Fjord \\
\hline IC037 & Ellis Fjord \\
\hline IC056 ( = ACAM 609) & Ellis Fjord \\
\hline $\operatorname{IC059}(=\operatorname{ACAM} 610)$ & Taynaya Bay \\
\hline $\operatorname{IC067^{\mathrm {T}}}\left(=\right.$ ACAM $\left.611^{\mathrm{T}}\right)$ & O`Gorman Rocks, Prydz Bay \\
\hline $\mathrm{IC} 070$ & Ellis Fjord \\
\hline $\mathrm{IC} 074$ & O'Gorman Rocks, Prydz Bay \\
\hline IC078 & O'Gorman Rocks, Prydz Bay \\
\hline IC083 & Ellis Fjord \\
\hline $\operatorname{IC085}(=$ ACAM 613) & Shirokaya Bay, Long Fjord \\
\hline $\mathrm{IC} 173$ & Ellis Fjord \\
\hline IC 181 & Ellis Fjord \\
\hline IC 185 & Ellis Fjord \\
\hline IC 186 & Ellis Fjord \\
\hline $\operatorname{IC187}(=\mathrm{ACAM} 614)$ & Ellis Fjord \\
\hline \multicolumn{2}{|l|}{ G. pallidula gen. nov., sp. nov. } \\
\hline $\operatorname{IC079^{\mathrm {T}}}\left(=\right.$ ACAM $\left.615^{\mathrm{T}}\right)$ & Taynaya Bay \\
\hline $\mathrm{IC} 178$ & Ellis Fjord \\
\hline $\mathrm{IC} 182(=\mathrm{ACM} 616)$ & Ellis Fjord \\
\hline \multicolumn{2}{|l|}{ A. macleodii subsp. macleodii } \\
\hline NCIMB $1963^{\mathrm{T}}$ & Seawater \\
\hline
\end{tabular}

* ACAM, Australian Collection of Antarctic Microorganisms, Antarctic CRC, University of Tasmania, Hobart, Tasmania, Australia; NCIMB, National Collection of Industrial and Marine Bacteria, Aberdeen, UK. 


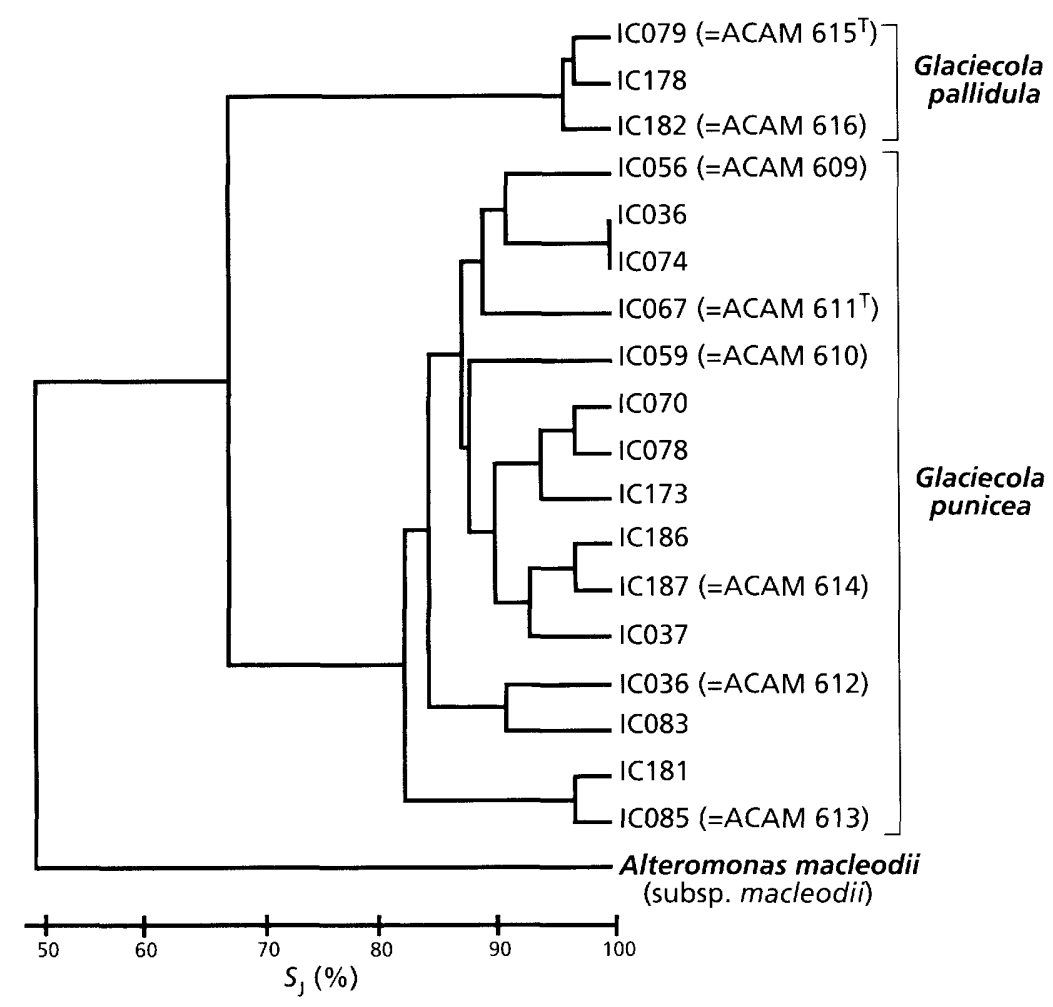

Fig. 1. Unweighted pair group mean dendrogram based on Jaccard similarity $\left(S_{1}\right)$ values obtained from phenotypic data (Table 2) for Glaciecola strains and $A$. macleodii subsp. macleodii.

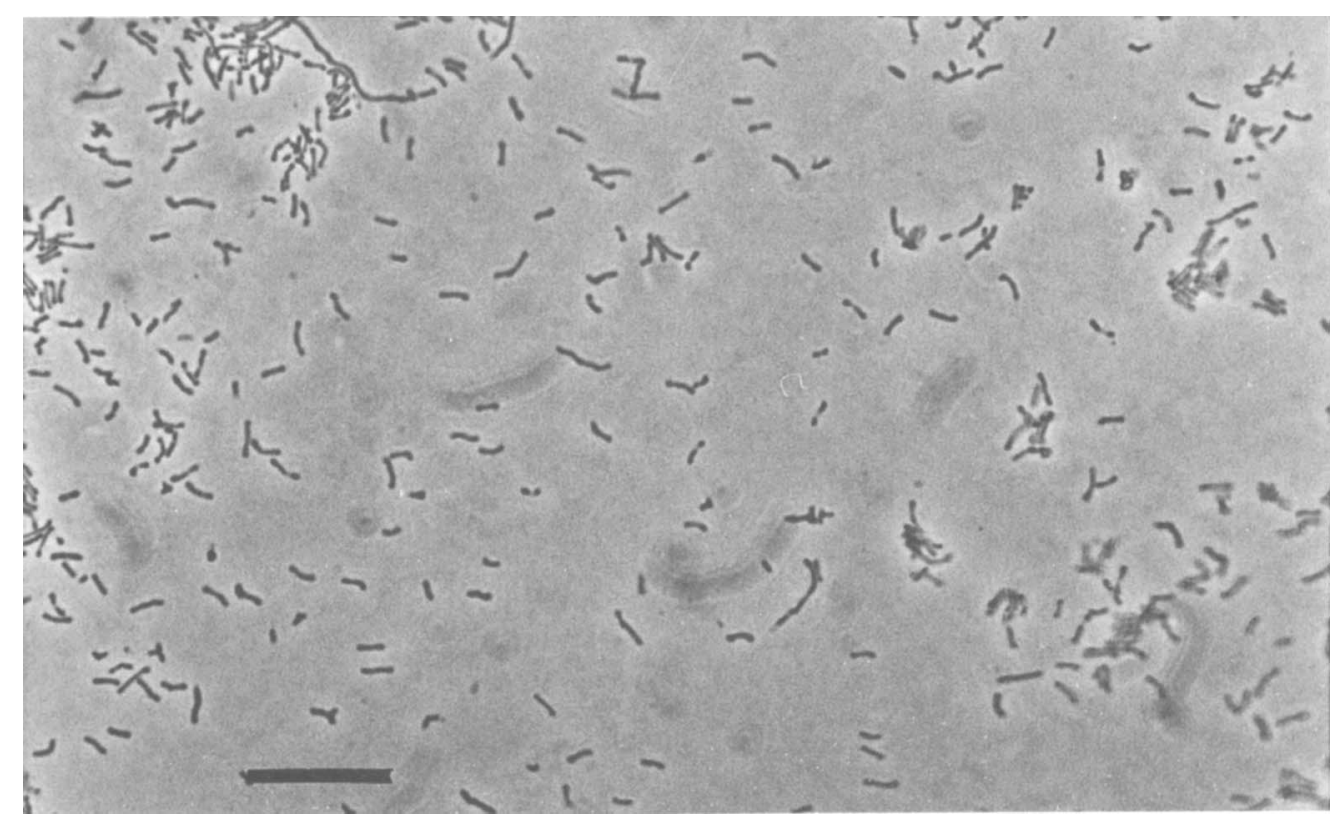

Fig. 2. Phase-contrast photomicrographs of G. punicea ACAM $611^{\top}$ grown in liquid marine 2216 media at $10^{\circ} \mathrm{C}$. Bar, $10 \mu \mathrm{m}$.

3-5 $\mathrm{mm}$ in diameter after $14 \mathrm{~d}$ incubation. All strains were similar in terms of cellular morphology, occurring as motile, slender, slightly curved to curved rod-shaped cells, $1-5 \mu \mathrm{m}$ in length and $0 \cdot 2-0 \cdot 4 \mu \mathrm{m}$ in width (Fig.
2). Strains of both phenetic groups may also possess a spiral-like morphology or occur as short filaments. These morphological variants occur frequently in stationary-phase cultures. 
Glaciecola gen. nov.

\section{Table 2. Phenotypic characteristics differentiating G. punicea and G. pallidula}

+ , Test positive for all strains; $v+$, variable results between strains, type strain positive; $v-$, variable results between strains, type strain negative; -, all strains negative for test; $(+)$, weak and delayed reaction. All strains were positive for the following tests: growth at $0-10{ }^{\circ} \mathrm{C}$; growth on marine 2216 agar, R2A seawater agar and Zobell's agar; production of catalase, cytochrome- $c$ oxidase, $\alpha$-galactosidase and $\beta$-galactosidase; acid production (weak and/or delayed) from Dglucose, D-galactose, D-melibiose and glycerol; and utilization of oxaloacetate as a sole carbon and energy source. All strains were negative for the following tests: growth at $25^{\circ} \mathrm{C}$ or higher; growth with $3 \times$ and $4 \times$ strength seawater, tolerance to $5 \%$ ox bile salts; nitrate as a nitrogen source; nitrate reduction, denitrification and nitrogen fixation; hydrolysis of urea, xanthine, egg yolk, casein, gelatin, chitin, dextran and DNA; production of L-phenylalanine deaminase, Ltryptophan deaminase, arginine dihydrolase, glutamate decarboxylase, lysine decarboxylase, ornithine decarboxylase, $\alpha$-glucosidase, $\beta$-glucosidase, $\alpha$-fucosidase, $\alpha$-arabinosidase, $\beta$ glucuronidase, $\beta$ - $N$-acetylglucosaminidase; indole from L-tryptophan; hydrogen sulfide from thiosulfate: acid production from L-arabinose, D-mannose, D-fructose, L-rhamnose, D-xylose, Dmannitol, $\mathrm{N}$-acetylglucosamine, sucrose, lactose, cellobiose, trehalose, D-raffinose, dextran, adonitol, L-arabitol, D-sorbitol and $m$-inositol; utilization of $N$-acetylglucosamine, L-arabinose, cellobiose, D-xylose, L-rhamnose, D-fructose, D-galactose, D-glucose, D-mannose, lactose, maltose, D-melibiose. D-raffinose, sucrose, trehalose, starch, chitin, adonitol, L-arabitol, i-erythritol, $m$ inositol, D-mannitol, D-sorbitol, D-gluconate, D-glucuronate, saccharate, propionate, isobutyrate, valerate, isovalerate, caproate, heptanoate, caprylate, nonanoate, malonate, adipate, glutarate, pimelate, azelate, trans-aconitate, citrate, 3-hydroxybutyrate, 2-oxoglutarate, L-alanine, Lasparagine. L-aspartate, L-histidine, L-leucine, L-phenylalanine, hydroxy- L-proline, L-ornithine, Lserine, L-threonine, putrescine, $\gamma$-aminobutyrate and urate.

\begin{tabular}{|c|c|c|}
\hline Characteristic & G. punicea $(n=15)$ & G. pallidula $(n=3)$ \\
\hline Pigmentation & Pink-red & Pale pink \\
\hline Yeast extract requirement & $v+$ & - \\
\hline$\beta$-Galactosidase-6-phosphate & + & - \\
\hline \multicolumn{3}{|l|}{ Hydrolysis of: } \\
\hline Urate & $v-$ & - \\
\hline Aesculin & $v+$ & - \\
\hline Starch & - & $v+$ \\
\hline Tween 80 & $v-$ & + \\
\hline Acid from maltose & - & $(+)$ \\
\hline \multicolumn{3}{|l|}{ Utilization of: } \\
\hline$\alpha$-Glycerophosphate & $v+$ & + \\
\hline $\begin{array}{l}\text { Succinate, L-malate, } \\
\text { fumarate, L-proline }\end{array}$ & + & - \\
\hline $\begin{array}{l}\text { Glycerol, glycogen, } \\
\text { acetate, pyruvate, DL-lactate, } \\
\text { L-glutamate }\end{array}$ & - & + \\
\hline L-Tyrosine & $v+$ & - \\
\hline Butyrate & - & $v-$ \\
\hline $\mathrm{G}+\mathrm{C}$ content by $T_{\mathrm{m}}(\mathrm{mol} \%)$ & $44-46$ & 40 \\
\hline
\end{tabular}

\section{Physiology and metabolism}

The physiological, biochemical and nutritional properties of the sea-ice strain taxa are shown in Table 2. The sea-ice isolates were strictly aerobic, seawaterrequiring chemoheterotrophs. The strains have an absolute requirement for seawater, growing between $0.5 \times$ and $1.5 \times$ seawater. Very poor or no growth occurred when the media was supplemented with only $\mathrm{NaCl}$. The strains were unable to grow anaerobically either by fermentation or anaerobic respiration. Only oxidative acid production from carbohydrates was observed and these reactions were weak and slow, taking up to $10 \mathrm{~d}$ to form on Leifson's $\mathrm{O} / \mathrm{F}$ medium. In marine 2216 broth, all strains grew between $-2{ }^{\circ} \mathrm{C}$ and $20^{\circ} \mathrm{C}$, with most $G$. punicea strains also able to grow slowly at $25^{\circ} \mathrm{C}$. None of the strains exhibited growth at $25^{\circ} \mathrm{C}$ and at best scanty growth at $20^{\circ} \mathrm{C}$ on marine 2216 agar plates.

\section{Enzyme production and nutrition}

The hydrolytic capacity of the strains was restricted, with a few strains of $G$. punicea able to slowly hydrolyse aesculin and uric acid whilst some $G$. pallidula strains 
J. P. Bowman and others

Table 3. DNA-DNA hybridization levels between representative Glaciecola strains

\begin{tabular}{|c|c|c|c|}
\hline \multirow[t]{2}{*}{ Species/strain } & \multirow{2}{*}{$\begin{array}{c}\mathrm{G}+\mathrm{C} \text { content } \\
\text { by } T_{\mathrm{m}} \\
(\mathbf{m o l} \%)\end{array}$} & \multicolumn{2}{|c|}{ DNA-DNA hybridization (\%)* } \\
\hline & & $\begin{array}{l}\text { G. punicea } \\
\text { ACAM } 611^{\mathrm{T}}\end{array}$ & $\begin{array}{r}\text { G. pallidula } \\
\text { ACAM } 615^{\mathrm{T}}\end{array}$ \\
\hline G. punicea ACAM 609 & $44 \cdot 8$ & 95 & NT \\
\hline G. punicea ACAM 610 & $45 \cdot 6$ & NT & NT \\
\hline G. punicea АСАM $611^{\mathrm{T}}$ & $43 \cdot 9$ & 100 & 18 \\
\hline G. punicea АСАM 612 & $45 \cdot 1$ & 85 & NT \\
\hline G. punicea ACAM 613 & $46 \cdot 3$ & 82 & NT \\
\hline G. punicea АCAM 614 & $46 \cdot 0$ & 91 & NT \\
\hline G. pallidula ACAM $615^{\mathrm{T}}$ & $40 \cdot 3$ & 18 & 100 \\
\hline G. pallidula ACAM 616 & $39 \cdot 5$ & 10 & 97 \\
\hline $\begin{array}{l}\text { A. macleodii subsp. macleodii NCIMB } \\
1973^{\mathrm{T}}\end{array}$ & $42 \cdot 0$ & 13 & 10 \\
\hline
\end{tabular}

NT, Not tested.

*Values based on the mean of 3-5 experimental replicates.

Table 4. Whole-cell fatty acid profiles of Glaciecola species and related genera

Standard deviations are given in parentheses. ND, Not tested.

\begin{tabular}{|c|c|c|c|}
\hline \multirow[t]{2}{*}{ Fatty acid } & \multicolumn{3}{|c|}{ Fatty acid composition (\%) } \\
\hline & G. punicea $(n=4)$ & G. pallidula $(n=2)$ & A. macleodii $(n=1)$ \\
\hline $13: 0$ & ND & $0 \cdot 1(0 \cdot 1)$ & 0.4 \\
\hline $14: 0$ & $1 \cdot 2(0 \cdot 4)$ & $3.6(0.2)$ & $3 \cdot 0$ \\
\hline $15: 0$ & $1 \cdot 0(0 \cdot 3)$ & $1 \cdot 6(0 \cdot 1)$ & $3 \cdot 7$ \\
\hline $16: 0$ & $10 \cdot 0(2 \cdot 2)$ & $9 \cdot 4(0 \cdot 4)$ & $25 \cdot 0$ \\
\hline $17: 0$ & $0.7(0.2)$ & $1 \cdot 3(0 \cdot 1)$ & $5 \cdot 6$ \\
\hline $18: 0$ & $0 \cdot 4(0 \cdot 1)$ & $0 \cdot 4(0 \cdot 1)$ & $1 \cdot 0$ \\
\hline $14: 1 \omega 7 c$ & $0.5(0.2)$ & $3 \cdot 7(0 \cdot 2)$ & $1 \cdot 1$ \\
\hline $14: 1 \omega 5 c$ & $\mathrm{ND}$ & $0 \cdot 2(0 \cdot 1)$ & ND \\
\hline $15: 1 \omega 8 c$ & $0 \cdot 8(0 \cdot 1)$ & $3 \cdot 4(0 \cdot 1)$ & $1 \cdot 3$ \\
\hline $15: 1 \omega 6 c$ & $0 \cdot 4(0 \cdot 1)$ & $0 \cdot 5(0 \cdot 1)$ & $0 \cdot 4$ \\
\hline $16: 1 \omega 7 c$ & $60 \cdot 7(0.7)$ & $54.2(1.9)$ & $34 \cdot 6$ \\
\hline $16: 1 \omega 5 c$ & $0 \cdot 1(0 \cdot 1)$ & $\mathrm{ND}$ & ND \\
\hline $17: 1 \omega 8 c$ & $4 \cdot 6(0 \cdot 5)$ & $5 \cdot 0(0 \cdot 3)$ & $8 \cdot 0$ \\
\hline $17: 1 \omega 6 c$ & $0 \cdot 4(0 \cdot 1)$ & $0 \cdot 6(0 \cdot 1)$ & $0 \cdot 3$ \\
\hline $18: 1 \omega 11 c$ & $\mathrm{ND}$ & ND & 0.6 \\
\hline $18: 1 \omega 9 c$ & $0 \cdot 2(0 \cdot 1)$ & $0 \cdot 2(0 \cdot 1)$ & $0 \cdot 3$ \\
\hline $18: 1 \omega 7 c$ & $16 \cdot 3(4 \cdot 3)$ & $12 \cdot 6(0 \cdot 4)$ & $9 \cdot 4$ \\
\hline $19: 1$ & ND & $\mathrm{ND}$ & $0 \cdot 2$ \\
\hline i13:0 & ND & $0 \cdot 3(0 \cdot 1)$ & $0 \cdot 4$ \\
\hline i14:0 & $\mathrm{ND}$ & $0.4(0 \cdot 1)$ & $0 \cdot 2$ \\
\hline i1 $5: 0$ & $0 \cdot 2(0 \cdot 1)$ & $\mathrm{ND}$ & $0 \cdot 1$ \\
\hline a 15:0 & ND & ND & 0.5 \\
\hline i16:0 & $1.8(0.8)$ & $2 \cdot 5(0 \cdot 3)$ & $2 \cdot 0$ \\
\hline i17:0 & $0 \cdot 5(0 \cdot 1)$ & $0 \cdot 1(0 \cdot 1)$ & $0 \cdot 4$ \\
\hline a17:0 & ND & $\mathrm{ND}$ & 0.6 \\
\hline $\mathrm{i} 17: 1 \omega 7 c$ & $0 \cdot 3(0 \cdot 1)$ & $\mathrm{ND}$ & ND \\
\hline $\begin{array}{l}\text { Mean } \\
\text { monounsaturated:saturated } \\
\text { fatty acid ratio }\end{array}$ & $5 \cdot 3(0 \cdot 3)$ & $4 \cdot 1(0 \cdot 4)$ & $1 \cdot 3$ \\
\hline
\end{tabular}




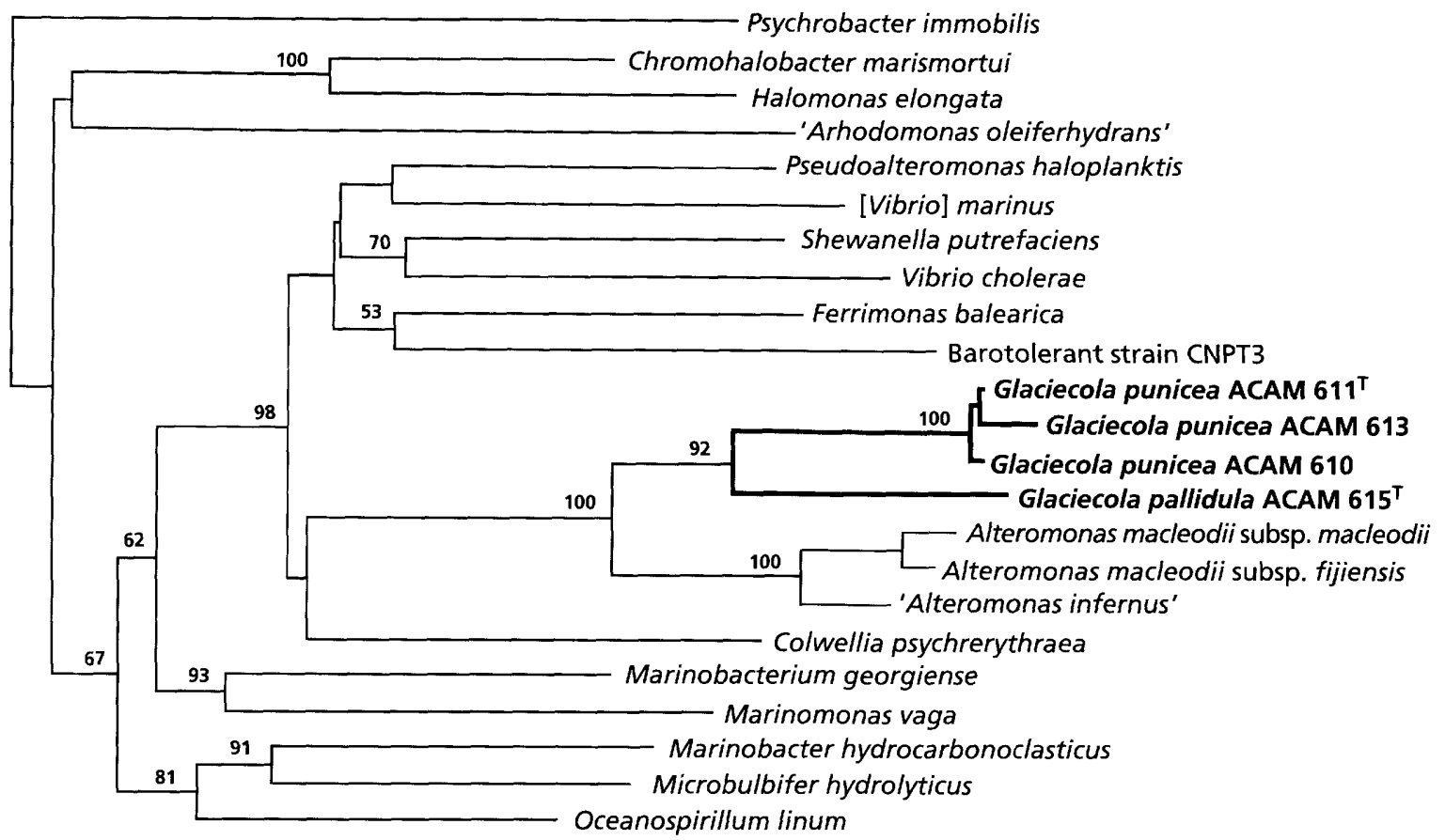

$5 \%$

Fig. 3. Phylogenetic tree constructed on the basis of $16 \mathrm{~S}$ rRNA sequences showing the relationship of $G$. punicea and $G$. pallidula to other marine chemoheterotrophs of the gamma subclass. The bar corresponds to a $5 \%$ difference in nucleotide sequences, as determined by measuring the length of horizontal lines connecting any two organisms. The numbers shown at branch points indicate percentage bootstrap values from 1000 data sets. Only bootstrap values greater than $60 \%$ are shown.

were able to hydrolyse starch. However, the strains were strongly catalase-and oxidase-positive, degraded Tween 80 and were able to form the following enzymes, as indicated by API 32 ID test kit results: alkaline phosphatase, $\alpha$-galactosidase and $\beta$-galactosidase. $G$. punicea strains could also form $\beta$-galactosidase-6phosphate. Though most of the strains could use ammonium chloride or ammonium sulfate as a nitrogen source, some strains of $G$. punicea were only able to grow with an organic nitrogen source, which could be supplied in the form of peptone or yeast extract. Vitamin growth factors were not required by any of the strains, but appeared to stimulate growth. The strains were able to utilize a limited number of substrates as sole carbon and energy sources, which were mostly organic acids, especially those related to the tricarboxylic acid cycle. Carbohydrates and alcohols were in general not utilized by the sea-ice strains (Table 2).

\section{DNA base composition and DNA-DNA hybridization}

G. punicea strains possessed a DNA $\mathrm{G}+\mathrm{C}$ content ranging from 44 to $46 \mathrm{~mol} \%$ (mean $45 \cdot 1 \pm 1 \cdot 0, n=9$ ), comparatively higher than G. pallidula which possessed a value of about $40 \mathrm{~mol} \%$ (mean $39 \cdot 8 \pm 0 \cdot 5, n=3$ ) (Table 3). G. punicea strains ACAM 610, ACAM $611^{\text {T }}$,
ACAM 612, ACAM 613 and ACAM 614 shared high DNA-DNA reassociation levels, ranging from 82 to $95 \%$ whilst exhibiting only low hybridization levels with $G$. pallidula strains ACAM $615^{\mathrm{T}}$ and ACAM 616 (levels of 10-19\%) (Table 3). G. pallidula strains were very similar, showing $97 \%$ DNA-DNA hybridization. Neither ACAM $611^{\mathrm{T}}$ or ACAM $615^{\mathrm{T}}$ exhibited any significant hybridization to $A$. macleodii subsp. macleodii (Table 3).

\section{Fatty acid profiles}

Representative strains possessed very similar wholecell fatty acid profiles and the major constituents included $16: 1 \omega 7 c(52-62 \%), 18: 1 \omega 7 c(12-21 \%), 16: 0$ $(9-12 \%)$ and $17: 1 \omega 8 c(4-5 \%)$ (Table 4). The strains also contained a number of iso-branched-chain fatty acids as minor components; however these are too low in relative concentration to be useful in distinguishing the two species (Table 4). Polyunsaturated fatty acids and hydroxylated fatty acids were either not present or present at only trace levels. The fatty acid profiles, though sharing many of the same fatty acid constituents as $A$. macleodii, were substantially more enriched in monounsaturated fatty acid, as reflected by the high ratio of monounsaturated fatty acid to saturated fatty acid content (Table 4). 


\section{Phylogeny}

The phylogenetic relationships of four sea-ice strains were examined by distance and maximum-likelihood methods. Strains of $G$. punicea (ACAM 610, ACAM $611^{\mathrm{T}}$ and ACAM 613) grouped closely together with a similarity ranging from $99 \cdot 0$ to $99 \cdot 7 \%$. G. pallidula ACAM $615^{\mathrm{T}}$ grouped more distantly at a similarity of 93.4-94.0\% ; however all four strains grouped monophyletically, supported by the high bootstrap value $(92 \%)$ at the branch node (Fig. 3). A. macleodii subsp. macleodii, A. macleodii subsp. fijiensis and ' $A$. infernus' were the closest relatives of the sea-ice strains, with a sequence similarity of $91.9-92.1 \%$ with ACAM $611^{\text {T }}$ and $89 \cdot 7-91 \cdot 1 \%$ with the $G$. punicea strains. As a result, the sea-ice strains form a distinct branch adjacent to $A$. macleodii within the Colwellia assemblage radiation of the gamma subclass (Fig. 3). The Colwellia assemblage contains several other genera also isolated from sea ice including species of Colwellia, Pseudoalteromonas and Shewanella (Bowman et al., 1997b).

\section{DISCUSSION}

Recent phenotypic and phylogenetic surveys of Antarctic sea-ice bacterial diversity detected the presence of several novel phylogenetic lineages within the gamma subclass of the Proteobacteria and within the Bacteroides-Flavobacterium-Flexibacter phylum (Bowman et al., 1997b). A lineage adjacent to Alteromonas included Gram-negative, motile, slightly halophilic psychrophiles with a rod-like morphology forming distinctive pink-red- or pale-pink-pigmented colonies on marine 2216 agar. The pigmentation made these isolates readily identifiable on sea-ice bacterial isolation media and the isolates were particularly evident from sea-ice samples which possessed welldeveloped sea-ice diatom assemblages. Preliminary evidence suggests these isolates are restricted entirely to sea-ice habitats as they so far have not been recovered from extensive sampling of under-ice seawater (Bowman et al., 1997a, b). Likewise, they appear to be absent from the water column of Burton Lake, a marine salinity, meromictic water body which has been noted for a substantial enrichment of psychrophilic bacteria within its oxic zone (Franzmann et al., 1990). The sea-ice strains making up this novel group were examined in this study to determine their taxonomic relationships. The novel taxa form two groups as shown by numerical taxonomic analysis (Fig. 1) and 16S rRNA sequence analysis (Fig. 3). Both groups have a relatively restricted biochemical and nutritional versatility (Table 2). Alteromonas species, the closest relatives, by comparison have a mesophilic growth temperature range, are significantly more halotolerant, and have a much greater nutritional versatility in terms of carbon substrates utilized and in the production of extracellular enzymes (Baumann et al., 1984; Raguenes et al., 1997). The phylogenetic relatedness of the sea-ice strains and $A$. macleodii is supported by the similar types of components making up their fatty acid profiles, including the presence of branched-chain fatty acids and general lack of hydroxylated fatty acids and polyunsaturated fatty acids. However, the differences in ecophysiology are indicated by the presence of a three- to fourfold higher monounsaturated fatty acid to saturated fatty acid ratio in the sea-ice strains. The capacity of the sea-ice strains to synthesize higher levels of monounsaturated fatty acid may be connected to cold adaptation processes, particularly associated with maintenance of cytoplasmic membrane homeoviscosity (Nichols et al., 1995).

On the basis of ecophysiological, phenotypic and phylogenetic differences, the sea-ice strains are proposed to form a taxonomic entity distinct from the genus Alteromonas. The sea-ice strain group can also be distinguished from other marine chemoheterotrophs belonging to the gamma subclass, including species of Shewanella, Colwellia and Marinobacter, which occupy the same sea-ice habitats (Table 5). From these conclusions, we propose that the sea-ice strains constitute a new genus, Glaciecola gen. nov. The genus Glaciecola contains two distinct species, including Glaciecola punicea gen. nov., sp. nov., which includes strains that have the characteristic pink-red pigmentation. The second group is designated Glaciecola pallidula gen. nov., sp. nov. and includes the pale-pink-pigmented strains.

\section{Description of Glaciecola gen. nov.}

Glaciecola (Gla.ci.e'co.la. L. fem. n. glacies ice; L. gen. $\mathrm{n}$. incola an inhabitant; M.L. fem. n. Glaciecola inhabitant of ice).

Cells are slender with a rod-like shape. Cells may be slightly curved, curved or spiral. Gram-negative, motile, non-sporulating, strictly aerobic chemoheterotroph. Psychrophilic and requiring seawater for growth. Slightly halophilic. Oxidase- and catalasepositive. Major fatty acids are hexadecaenoic acid $(16: 1 \omega 7 c)$, hexadecanoic acid $(16: 0)$ and octadecaenoic acid $(18: 1 \omega 7 c)$. DNA $\mathrm{G}+\mathrm{C}$ content is 40-46 $\mathrm{mol} \%$ (determined from thermal denaturation curves, $T_{\mathrm{m}}$ ). Member of the gamma subclass of the Proteobacteria. Antarctic sea-ice diatom assemblages are the only known habitat. Type species is Glaciecola punicea.

\section{Description of Glaciecola punicea sp. nov.}

Glaciecola punicea (pu.nice'a. L. fem. adj. punicea pink-red, referring to the species pigmentation).

Same as genus description plus the following. Temperature optimum is about $15^{\circ} \mathrm{C}$ and temperature maximum is $20-25^{\circ} \mathrm{C}$. Some strains require yeast extract for growth and growth is stimulated by vitamin growth factors. Oxidative acid production from carbohydrates is weak and delayed and may be formed from D-glucose, D-galactose, D-melibiose and glycerol. Some 
Table 5. Phenotypic traits differentiating the genus Glaciecola from other phylogenetically related marine chemoheterotrophic bacteria of the gamma subclass

+ , Trait present; $\mathrm{V}$, varies between species of genus; - , trait absent.

\begin{tabular}{|c|c|c|c|c|c|c|c|c|}
\hline Genus & $\begin{array}{c}\text { Known } \\
\text { habitats* }\end{array}$ & Pigmentation & $\begin{array}{c}\text { Cellular } \\
\text { morphology }\end{array}$ & $\begin{array}{l}\text { Psychrophilic } \\
\text { growth }\end{array}$ & $\begin{array}{c}\text { Growth with } \\
10 \% \mathrm{NaCl}\end{array}$ & $\begin{array}{c}\text { Facultatively } \\
\text { anaerobic }\end{array}$ & $\begin{array}{c}\text { PUFA } \\
\text { production } \dagger\end{array}$ & $\begin{array}{l}\mathrm{G}+\mathrm{C} \text { content } \\
\text { by } T_{\mathrm{m}}(\mathrm{mol} \%)\end{array}$ \\
\hline Glaciecola & I & $\begin{array}{l}\text { Pink red or } \\
\text { pale pink }\end{array}$ & $\begin{array}{l}\text { Curved- } \\
\text { straight rods, } \\
\text { spiral }\end{array}$ & + & - & - & - & $40-46$ \\
\hline Alterominas & sw & None & Straight rods & - & + & - & - & 4447 \\
\hline Pseudoalteromonas & I, SW & $\begin{array}{l}\text { None, yellow, } \\
\text { orange, red or } \\
\text { violet }\end{array}$ & $\begin{array}{l}\text { Straight or } \\
\text { curved rods }\end{array}$ & - & $\mathrm{v}$ & - & - & $37-45$ \\
\hline Ferrimonas & B & Pink-tan & Straight rods & - & - & + & - & $50-52$ \\
\hline Shewanella & $\begin{array}{l}\text { I, SW, B. } \\
\text { D, W, F, C }\end{array}$ & $\begin{array}{l}\text { None or pink- } \\
\tan \end{array}$ & $\begin{array}{l}\text { Straight/curved } \\
\text { rods }\end{array}$ & $\mathrm{v}$ & $\mathrm{v}$ & + & $\mathrm{V}(\mathrm{EPA})$ & $40-54$ \\
\hline Colvellia & I, SW, B, D & None & Curved rods & + & - & + & $+(\mathrm{DHA})$ & $35-46$ \\
\hline [Vibrie] marrius & SW, B, D & None & $\begin{array}{l}\text { Straight/curved } \\
\text { rods }\end{array}$ & + & - & + & $+(\mathrm{DHA})$ & 42 \\
\hline
\end{tabular}

*I, sea ice; SW, seawater (includes marine salinity lakes, decaying seaweed and fish etc.); B, benthic sediments; D, deep-sea sites (including the intestines of deep sea fish); W, freshwater; $\mathrm{C}$, clinical samples; $\mathrm{F}$, food samples.

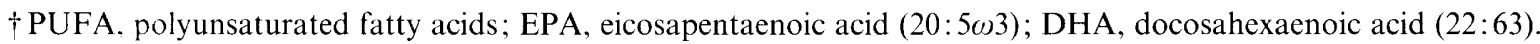

$¥$ May form gas vesicles.

strains slowly degrade uric acid, aesculin or L-tyrosine. The enzymes $\alpha$-galactosidase, $\beta$-galactosidase, $\beta$ galactosidase-6-phosphate and alkaline phosphatase are formed. Utilizes the following substrates as carbon and energy sources: succinate, L-malate, fumarate, oxaloacetate and L-proline. Some strains can utilize $\alpha$ glycerophosphate. Other phenotypic and biochemical test results are shown in Table 2. Colonies have a bright pink-red pigment, are circular and convex in shape, with an entire edge and possessing a butyrous consistency. DNA G + C content is $4446 \mathrm{~mol} \%\left(T_{\mathrm{m}}\right)$. Isolated from Antarctic sea-ice diatom assemblages. Type strain is ACAM $611^{\mathrm{T}}$ isolated from a sea-ice core collected from the O'Gorman Rocks area of Prydz Bay, Antarctica.

\section{Description of Glaciecola pallidula sp. nov.}

Glaciecola pallidula (pal.lid'u.la. L. adj. pallidula somewhat pale, referring to the weak pigmentation of the species).

Same as genus decription plus the following. The temperature optimum is $10-15^{\circ} \mathrm{C}$ and the temperature maximum is $18-20^{\circ} \mathrm{C}$. Nutritionally non-exacting but growth is stimulated by the addition of vitamin growth factors. Oxidative acid production from carbohydrates is weak and delayed and may be formed from Dglucose, D-galactose, maltose, D-melibiose and glycerol. Tween 80 is hydrolysed and the enzymes $\alpha$ galactosidase, $\beta$-galactosidase and alkaline phosphatase are formed. Strains may also slowly degrade starch. Utilizes the following substrates as carbon and energy sources: glycogen, glycerol, $\alpha$-glycerophosphate, acetate, pyruvate, DL-lactate, oxaloacetate and L-glutamate. Some strains can also utilize butyrate. Other phenotypic and biochemical test results are shown in Table 2. Colonies are pale pink, circular, raised convex, with entire edges and a butyrousmucoid consistency. DNA G $+\mathrm{C}$ content is $40 \mathrm{~mol} \%$ $\left(T_{\mathrm{m}}\right)$. Isolated from Antarctic sea-ice diatom assemblages. Type strain is ACAM $615^{\mathrm{T}}$ isolated from seaice cores collected from Taynaya Bay, Antarctica.

\section{ACKNOWLEDGEMENTS}

This work was supported by the Australian Research Council (grant A19602517) and Antarctic Science Advisory Committee (ASAC Project no. 1012). We would like to thank David Nichols and Peter Nichols for assistance in the fatty acid analysis, Suzy Rea for the testing of iron reduction, and Paul Holloway for critical evaluation of the manuscript and discussions.

\section{REFERENCES}

Altschul, S. F., Gish, W., Miller, W., Myers, E. W. \& Lipman, D. J. (1990). Basic local alignment search tool. J Mol Biol 215, 403-410.

Baumann, P., Gauthier, M. J. \& Baumann, L. (1984). Genus Alteromonas Baumann, Baumann, Mandell and Allen 1972, $418^{\mathrm{AL}}$. In Bergey's Manual of Systematic Bacteriology, vol. 1, pp. 343-352. Edited by N. R. Krieg \& J. G. Holt. Baltimore: Williams \& Wilkins.

Bowman, J. P., Brown, M. V. \& Nichols, D. S. (1997a). Biodiversity and ecophysiology of bacteria associated with Antarctic sea ice. Antarct Sci 9, 134-142.

Bowman, J. P., McCammon, S. A., Brown, M. V., Nichols, D. S. \& McMeekin, T. A. (1997b). Diversity and association of psychrophilic bacteria in Antarctic sea ice. Appl Environ Microbiol 63, 3068-3078.

Delille, D. (1996). Biodiversity and function of bacteria in the Southern Ocean. Biodivers Conserv 5, 1505-1523.

Dieckmann, G. S., Arrigo, K. R., Gosselin, M. \& Sullivan, C. W. (1992). A high resolution sampler for nutrient and chlorophyll 
profiles of the sea ice platelet layer and underlying water column below fast ice in polar oceans: preliminary results. Mar Ecol Prog Ser 80, 291-300.

Eicken, H. \& Lange, M. (1989). Development and properties of sea ice in the coastal regime of the southeastern Weddell Sea. $J$ Geophys Res 94, 8193-8206.

Felsenstein, J. (1993). PHYLIP (phylogeny inference package), version $3.57 \mathrm{c}$. http://evolution.genetics.washington.edu/ phylip.html

Franzmann, P. D., Deprez, P. P., McGuire, A. J., McMeekin, T. A. \& Burton, H. R. (1990). The heterotrophic bacterial microbiota of Burton Lake, Antarctica. Polar Biol 10, 261-264.

Gosink, J. J. \& Staley, J. T. (1995). Biodiversity of gas vacuolate bacteria from Antarctic sea ice and water. Appl Environ Microbiol 61, 3486-3489.

Grossi, S. M., Kottmeier, S. T. \& Sullivan, C. W. (1984). Sea ice microbial communities. III. Seasonal abundance of microalgae and associated bacteria, McMurdo Sound, Antarctica. Microb Ecol 10, 231-242.

Hungate, R. E. (1968). A roll tube method for cultivation of strict anaerobes. Methods Microbiol 3B, 117-132.

Huss, V. A. R., Festl, H. \& Schleifer, K.-H. (1983). Studies on the spectrophotometric determination of DNA hybridization from renaturation rates. Syst Appl Microbiol 4, 184-192.

Irgens, R. L., Suzuki, I. \& Staley, J. T. (1989). Gas vacuolate bacteria obtained from marine waters of Antarctica. Curr Microbiol 18, 261-265.

Leifson, E. (1963). Determination of carbohydrate metabolism of marine bacteria. J Bacteriol 85, 1183-1184.

Lovely, D. R. \& Phillips, E. J.P. (1986). Organic matter mineralization with reduction of ferric iron in anaerobic sediments. Appl Environ Microbiol 54, 683-689.

Marmur, J. \& Doty, P. (1962). Determination of the base composition of deoxyribonucleic acid from its thermal denaturation temperature. $J$ Mol Biol 5, 109-118.

Nichols, D. S. \& Russell, N. J. (1996). Fatty acid adaptation in an Antarctic bacterium - changes in primer utilization. Microbiology 142, 747-754.
Nichols, D. S., Nichols, P. D. \& McMeekin, T. A. (1995). Ecology and physiology of psychrophilic bacteria from antarctic saline lakes and sea ice. Sci Prog 78, 311-347.

Overmann, J. \& Pfennig, N. (1989). Pelodictyon phaeoclathratiforme sp. nov., a new brown-colored member of the Chlorobiaceae forming net-like colonies. Arch Microbiol 152, 401-406.

Palmisano, A. C. \& Garrison, D. L. (1993). Microorganisms in Antarctic sea ice. In Antarctic Microbiology, pp. 167-218. Edited by E. I. Friedmann. New York: Wiley-Liss.

Raguenes, G. H. C., Peres, A., Ruimy, R., Pignet, P., Christen, R., Loaec, M., Rougeaux, H., Barbier, G. \& Guezennec, J. G. (1997). Alteromonas infernus sp. nov., a new polysaccharide-producing bacterium isolated from a deep-sea hydrothermal vent. $J$ Appl Microbiol 82, 422-430.

Ross, D. \& Shields, K. (1993). TAXON personal computer program, version 1.0. Canberra: CSIRO Division of Entomology.

Sly, L. I., Blackall, L. L., Kraat, P. C., Tian-Shen, T. \& Sangkhobol, V. (1986). The use of second derivative plots for the determination of $\mathrm{mol} \%$ guanine plus cytosine of DNA by the thermal denaturation method. J Microbiol Methods 5, 139-156.

Smibert, R. M. \& Kreig, N. R. (1994). Phenotypic characterization. In Methods for General and Molecular Microbiology, pp. 611-654. Edited by P. Gerhardt, R. G. Murray, W. A. Wood \& N. R. Krieg. Washington, DC: American Society for Microbiology.

Staley, J. T., Fuerst, J. A., Giovannoni, S. \& Schlesner, H. (1992). The order Planctomycetales, and the genera Planctomyces, Pirellula, Gemmata, and Isosphaera. In The Prokaryotes, 2nd edn, vol. IV, pp. 3710-3731. Edited by A. Balows, H. G. Trüper, M. Dworkin, W. Harder \& K.-H. Schleifer. New York: Springer.

West, P. A. \& Colwell, R. R. (1984). Identification and classification of the Vibrionaceae - an overview. In Vibrios in the Environment, pp. 285-363. Edited by R. R. Colwell. New York: Wiley.

Widdel, F. \& Bak, F. (1992). Gram-negative mesophilic sulfatereducing bacteria. In The Prokaryotes, 2 nd edn, vol. IV, pp. 3352-3378. Edited by A. Balows, H. G. Trüper, M. Dworkin, W. Harder \& K.-H. Schleifer. New York: Springer. 